\title{
Management in Bulgaria
}

\author{
Interview with Marin Ignatov
}

Whoever reads the newspapers about Bulgaria in these days considers the situation first of all as a quite shaky one. Bulgaria seems to stand now at the turnover point of its political and economic reforms and a Western spectator is somewhat puzzled about all the processes which happen there.

Nevertheless, JEEMS always attempted to have a closer look and to present a deeper in-sight perspective of the problems in Eastern Europe. Therefore, we asked our corresponding member Marin Ignatov* to answer a few questions about the situation in his home country.

Dr. Marin Ignatov is Senior Research Fellow at the Bulgarian Academy of Sciences in Sofia. He majored in Work and Organizational Psychology at the University of Technology - Dresden, Germany. He is organizational consultant in several international East-European enterprise restructuring projects (PHARE, Carl-Duisburg-Gesellschaft). His special domain are the sociocultural difficulties in Joint Ventures, Mergers and Aquisitions. He also published on International Communication and Negotiation Skills. He was Visiting Professor at several Universities in Germany, Austria, UK, and USA. At present he is working on a German - Bulgarian research project on implicit behavioural safety rules.

Thomas Steger 
Professor Ignatov, could you, first of all, give a brief introduction about how you view the current political situation in Bulgaria?

The history of economic reform in Bulgaria dates back over 30 years. Increasingly aware of the shortcomings of the socialist system, dozens of official committees and hundreds of economists tried to reconcile the unreconcilable. The market was supposed to play a more effective role without undermining imperative central planning, enterprise and individual initiative was supposed to be unleashed without challenging the Bulgarian Communist Party's exclusive right to control every aspect of economic and social activity. This could not work. Whenever a critical choice had to be faced and suggested economic changes required changes in the political system, considerations of ideology and power prevailed over economic pragmatism. As a result, the crisis facing the Bulgarian economy continued to deepen even after the Perestroyka of 1989 - 1990. In the absence of a real market test, an increasing number of enterprises were maintained in existence by means of heavy government subsidies whereby the partners traded shoddy goods at prices that bore no relation to real costs.

The scene for real economic reform had to be set by means of political changes. Nothing less than a political revolution was required - one that would transform the very nature of the system rather than making mere cosmetic changes. Attempts in this direction can be seen in the Perestroyka stage of 1989 - 1990. Although these attempts were strangled by Communist manipulation, the foundations of the political system were undermined. Finally, in the end of 1996 the historic chance for Bulgaria could not be missed. And it has not been missed, thanks to the determination of the people and the opposition Union of Democratic Forces, and to passive or even active complicity of some communist politicians who were able to recognise that without democracy and fundamental economic reform Bulgaria had no future.

How would you assess the situation of Bulgarian Management? Are there any changes, a new elite, or do we find more a reproduction of the old ones?

It is too early now to make a precise assessment. Most probably politics will continue to play a critical role in Bulgarian management. Healthy business activity requires political stability which, however, has yet to be achieved in the country. While the overall trend towards political democracy appears to be irreversible, progress made so far in installing market-oriented managerial systems and practices has not been the same in all branches or regions of the country. The democratic forces were united in the winter of 1996-1997 in their effort to defeat the Communist regime, but this unity may weaken in the near future and divergent views on future development strategy may emerge. The restructuring of the governmental machinery and staffing changes have barely started. In the months and years to come, economic reforms win be hence 
interwoven with political reforms. The success in the isolation of the old Communist Nomenclature may speed up or slow down the economic reforms and strongly influence the implementation of structural changes, The difficulties to be overcome must not be underestimated.

\section{What about women in Management in Bulgaria?}

Women managers in Bulgaria are still a tiny minority. A restricted rise of the percentage of women managers could be expected in the sectors textiles, food and beverages industry.

Are there any activities to establish management associations? How would you evaluate their influence, for example in comparison with the unions?

Management Associations are still in a process of restructuring. Their influence as independent bodies is increasing. A positive attitude towards market orientation is characteristic for the Bulgarian Business Association in Sofia (Bulgarska stopanska kamara).

\section{What are the main deficits of today's Bulgarian managers?}

Economic reforms are creating a new framework, new conditions and new pressures for enterprise management. They are establishing fundamental conditions for change in the behaviour of the enterprise. Whether enterprises are fully or partially privatised, or continue to operate as semi state-owned organisations, their success will depend, first and foremost, on the vision and quality of their management. The market economy environment alone cannot and will not make everybody equally efficient and successful. In the current debate on the strategy and tactics of economic reforms in Bulgaria this tends to be overlooked. There is a tendency to expect miracles from managers and hence to concentrate on their managerial deficits. I would therefore reverse the question - Who would ensure the basic attitudinal changes in the country towards market success assessment and market remuneration for managers?

Are there any changes in values, attitudes or leadership styles of Bulgarian managers in comparison with the past (for example since privatisation)?

The bulk of the enterprises in Bulgaria is still not privatised. Privatisation is a crucial but difficult topic both technically and politically. In 1997 Bulgaria is not in a position to handle selected individual cases of privatisation within wellestablished market economies, as was done in France or Great Britain in the 1980s, but massive privatisation in all sectors with a view to creating a market economy from scratch. Company evaluation is a most delicate issue since there are divergent views on real value in the absence of financial markets and objective efficiency criteria, and due to widespread fears that public property will be given away to foreign investors at low prices. 
Improving productivity and quality will be the overriding dimension of privatisation and structural adjustment. With a few exceptions, Bulgarian industry is entering the reform process with productivity levels that are far below those of the industrially developed countries. In the short-term, the uncertain future of many enterprises and the expectation of major ownership and structural changes will tend to distract management's attention from productivity and quality.

What are the main strategies of enterprise management to ensure the survival and growth of their firms?

Reorienting enterprise management from command to market economy will call for a wide range of changes touching on virtually all functions and aspects of enterprise management, Functions that were underdeveloped or suppressed under the Communist economy, such as financial management and accounting, and the use of the money markets, will have to be gradually built up in harmony with the development of the market economy infrastructure and the internationalisation of business linkages. The need for a complete overhaul of functions such as corporate strategy, marketing and finance is largely recognised. Production management will lose the privileged position enjoyed in an economy of shortage, and will have to be reoriented in the spirit of service to customers, flexibility in adjusting to the market, optimum resource utilisation and efficiency.

What Bulgarian managers have to achieve has a common denominator whatever the economic sector or size of the enterprise. the organisational change will be far-reaching, extremely fast, and in many cases brutal and dramatic. Most of the managers concerned will have never managed or even witnessed such a change, where technical and business considerations will be closely interwoven with human, cultural and political problems.

Finally, just a short statement: what do you consider the main obstacle at the moment for management change in Bulgaria?

A market economy infrastructure will have to be developed in parallel with progressive liberation and privatisation. This includes the establishment of stock, financial, real estate and commodity markets, the development of commercial and investment banking, greatly improved telecommunications, private economy type wholesale and retail trade, accounting, information processing, taxation and tax collection services, business licensing and registration offices, labour market services, and so on.

Professor Ignatov, thank you very much for your answers! 